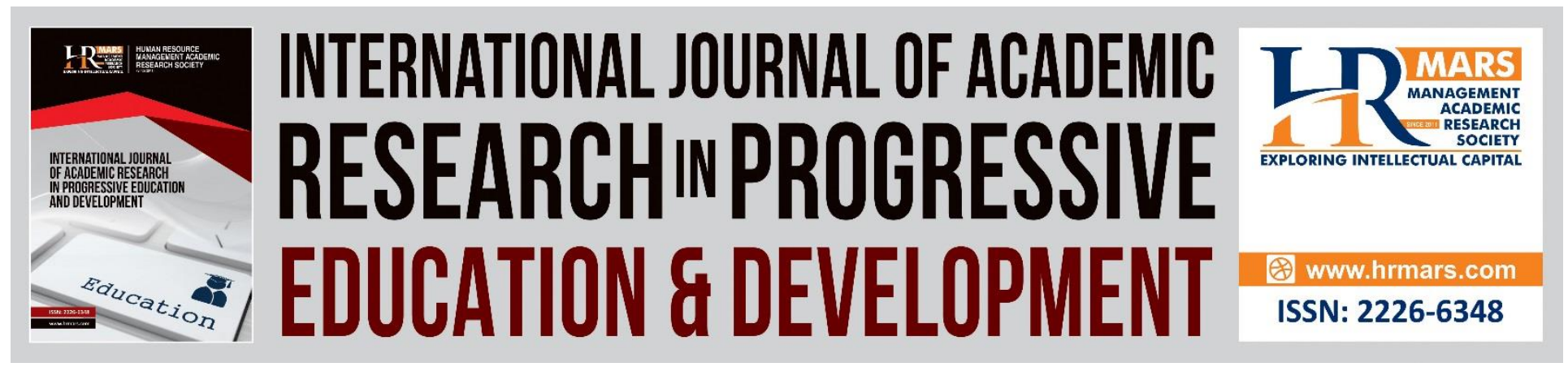

\title{
The Effectiveness of Reference Services and Users' Satisfaction in the Academic Library
}

Fatin Raudah Mohd Hussien \& Wan Nor Haliza Wan Mokhtar

To Link this Article: http://dx.doi.org/10.6007/IJARPED/v7-i3/4370 DOI: 10.6007/IJARPED/v7-i3/4370

Received: 11 June 2018, Revised: 26 June 2018, Accepted: 18 July 2018

Published Online: 29 July 2018

In-Text Citation: (Hussien \& Mokhtar, 2018)

To Cite this Article: Hussien, F. R. M., \& Mokhtar, W. N. H. W. (2018). The Effectiveness of Reference Services and Users' Satisfaction in the Academic Library. International Journal of Academic Research in Progressive Education and Development, 7(3), 327-337.

\section{Copyright: (C) 2018 The Author(s)}

Published by Human Resource Management Academic Research Society (www.hrmars.com)

This article is published under the Creative Commons Attribution (CC BY 4.0) license. Anyone may reproduce, distribute, translate and create derivative works of this article (for both commercial and non-commercial purposes), subject to full attribution to the original publication and authors. The full terms of this license may be seen

at: http://creativecommons.org/licences/by/4.0/legalcode

Vol. 7, No. 3, July 2018, Pg. 327 - 337

http://hrmars.com/index.php/pages/detail/IJARPED

JOURNAL HOMEPAGE

Full Terms \& Conditions of access and use can be found at http://hrmars.com/index.php/pages/detail/publication-ethics 


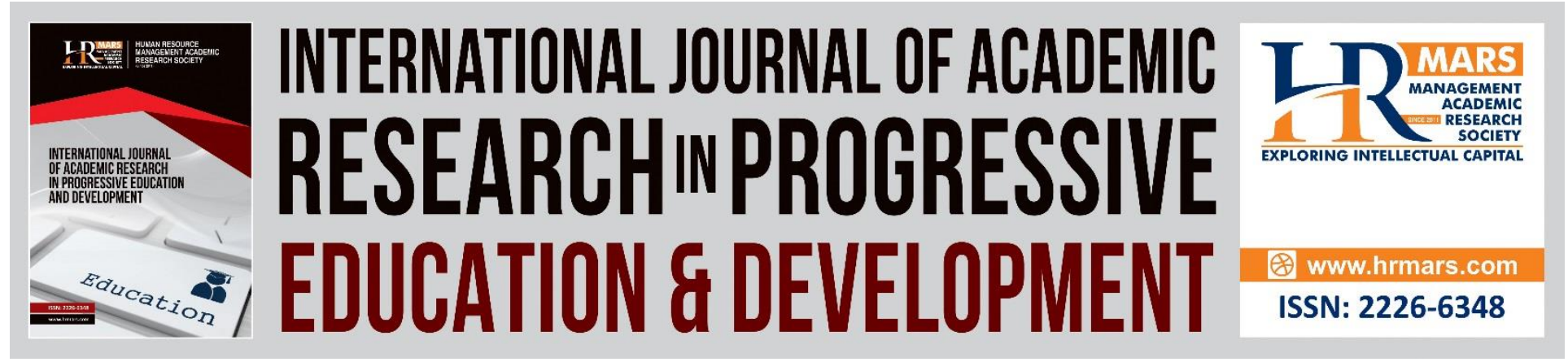

\title{
The Effectiveness of Reference Services and Users' Satisfaction in the Academic Library
}

\author{
${ }^{1}$ Fatin Raudah Mohd Hussien \& ${ }^{2}$ Wan Nor Haliza Wan Mokhtar \\ Faculty of Information Management, University Teknologi MARA, Puncak Perdana Campus, \\ Shah Alam, Selangor, Malaysia \\ Email: 1fatinraudah@gmail.com ${ }^{2}$ whaliza@salam.uitm.edu.my
}

\begin{abstract}
Library reference service is seen as one of the important activities that should be taken into consideration by the libraries to improve visibility and retain their relevancy. To have effective reference service for library users, it is essential for the libraries to maintain the accessibility, responsiveness, quality of answers and librarians' communication. This study presents the effectiveness of reference services (service accessibilities, responsiveness of librarians, quality of librarians' answers and librarians' communication approaches) and its relationships with users' satisfaction. Questionnaires were distributed to 231 random students who are using the academic library reference services. The analysis was undertaken using the SPSS software. The results indicate a positive and a weak relationship between service accessibilities, responsiveness of librarians, the quality of librarians' answers, librarians' communication approaches and users' satisfaction. The finding of the study is useful for the libraries to realize their performance towards the users of the libraries. The libraries should improve reference services and vigorously make promotions on the services offered in order to ensure the libraries are still important and relevant in this era.
\end{abstract}

Keywords: Reference Service, Digital Reference Service, User Satisfaction, Academic Library, Library Science

\section{Introduction}

Library institution is one of the entities that are important to the academic institutions. This is because library function is to provide a variety of sources and services in order to assist the community of the academic organization. As mentioned before, the library has many sources and services offered and it is not impossible if there are among of the community who do not know about how to find the appropriate services or sources that meet with their information needs. Therefore, in order to guide the users who are not familiar with the other library services and sources, reference service is one of the library services that they can seek for help. Reference service is one of the essential services that should be provided by any library organization. It is 
Vol. 7, No. 3, July 2018, E-ISSN: 2226-6348 @ 2018 HRMARS

considered as the heart of library services by several authors in their works (Das, Gurey, \& Saha, 2009; Ranasinghe, 2012). Therefore, it is important to conduct evaluations to identify the existing problem or deficiencies in order to ensure the service is running successfully (Luo \& Buer, 2015). Reference services began in the late nineteenth century with the purpose of assisting the inexperienced, unskilled readers and scholars in using library services and resources (Das, Gurey, \& Saha, 2009). Reference service is also called as reference and information services where it refers to personal assistance that provides information needed by the library users (Burge, 1999 as cited in Chowdary, 2002). Nowadays, it can be seen that many reference services approach available not only in traditional form but also in digital form which allows the users to communicate with the librarians virtually and indirectly make the librarians become more transparent to the library users. Thus, by having a good relationship with the library users it can increase the users' satisfaction on the library service and can encourage them to continuously use the library services and resources. Library users' satisfaction plays a vital role in the development and provision of the library by evaluating their feedback on the service (Sriram \& Rajev, 2014). As for the academic libraries, all the feedback regarding the library services, resources and facilities need to be given serious attention to ensure the users' needs and expectation could be fulfilled. At the same time the problems faced by the users in accessing their information needs could be reduced if the services, resources and facilities provided by the libraries are sufficient. Therefore, in order to get related feedback, a survey on the reference service and user's satisfaction should be conducted.

This paper describes the results of the study which aims to investigate the relationship between the effectiveness of reference services and user's satisfaction. The objectives are:

a) To identify the relationship between service accessibilities and users' satisfaction towards reference services.

b) To identify the relationship between the responsiveness of librarians and users' satisfaction towards reference services.

c) To identify the relationship between the quality of librarians' response and users' satisfaction towards reference services.

d) To identify the relationship between the librarians' communication skills and users' satisfaction towards reference services.

\section{Literature Review}

\section{Reference Service}

Reference service has been implemented in the library since ages. This service has been established almost 140 years ago. It has been implemented since 1876 at all types of American libraries (Deng, 2014). Among all the library functions, reference services are one of the services that really connected between the library and the users. It is a primary practice in the library organization as it is closely related with the users in fulfilling their needs. Because of that nature, many scholars at the beginning like Samuel Sweet Green, Margaret Hutchins and Samuel Rothstein attempt to do in depth studies on reference services in order to have a better understanding about it (Deng, 2014). One of the earliest definitions of reference services was 
INTERNATIONAL JOURNAL OF ACADEMIC RESEARCH IN PROGRESSIVE EDUCATION AND DEVELOPMENT

Vol. 7, No. 3, July 2018, E-ISSN: 2226-6348 @ 2018 HRMARS

made by James Wyer in 1929. He defines reference work as "direct sympathetic and informed personal aid in interpreting library collections for study and research" (Wyer, 1930 as cited in Deng, 2014). Then, it has been expanded by many researchers according to their understanding on reference services.

\section{Service Accessibilities}

Service accessibility is one of the important elements in evaluating the effectiveness of the reference services. Accessibility derives from the word "access" that defined as the right or opportunity to approach, enter, use or benefit from something (Glory, 2014). It shows how products and services are available to as many people as possible. Meanwhile, another researcher defines the accessibility of a service is a measure of how easily potential users are able to avail themselves of the service (McClure, Lankes, Melissa \& Choltco-Devlin, 2002). Among of the factors that be evaluated in these elements are the availability of the services either across the day or time, the site design (simplicity of interface), ease of use of the service and multilingual capabilities in both interface and staff. Study by Stacy-Bates (2003) discovers that accessibility in terms of the services between affiliates and non-affiliates of the institution has been conducted. Besides that, the study also meant to identify whether the queries are successfully received by the librarians.

\section{Responsiveness Of Librarian}

Users have intention to use the library services because they have high expectation that librarians are the information professionals who will help them in getting their information. Thus, librarians should always give good response towards users' queries. Therefore, they will not feel neglected. Siti, Norliya and Kasmarini (2012), McCrea (2004) and Stacy-Bates (2003), highlight that responsiveness is related to response received, in terms of response time or response rate. Timeliness is a key factor in service effectiveness and by giving the estimated time for the library's response, helps to assure the users in obtaining the relevance service from the libraries (StacyBates, 2003). Meanwhile, Wang and Shieh (2006), describe responsiveness as library staff's willingness to help users by providing prompt services to the users. Therefore, from the explanation gathered, it can be concluded that responsiveness is a willingness of librarians to help users in getting what they want by a given time that meet the users' expectation and preferences.

\section{Quality Of Librarian's Answer}

There are several elements that need to be considered in evaluating the quality of the answer. It includes accuracy, completeness, adequacy of the answer, referencing of sources, appropriate response, opportunity for interactivity and the level of instruction provided during the reference transaction (Ramos \& Abrigo, 2012; Siti, Norliya \& Kasmarini, 2012; McCrea, 2004). Based on the literature of previous study, it can be concluded that quality of the answer relates to the accuracy, validity and reliability of the information provided by the librarians or information providers. It will measure on the answers provided by the librarians whether it is exhaustive enough or otherwise. As discussed before, by using digital reference services, it allows the librarians to have ample time to search for the right materials. Thus, the accuracy of the information can be 
Vol. 7, No. 3, July 2018, E-ISSN: 2226-6348 @ 2018 HRMARS

fulfilled. This is important because users' satisfaction is one of the most important element that need to be considered by the academic libraries (Wan Nor Haliza, Siti and Dang, 2012).

\section{Communication Approaches}

It can be seen that, nowadays communication skills is very crucial in the service sectors especially to the librarians. Librarians need to frequently interact with the users so that they will have good relationships in terms of information transfer and delivery. By having a good realtionship between them, librarians can get as much information from the users about their feedback on the existing services in fulfilling users' needs and demands. Good communication and interpersonal relations provide the necessary skills for reference librarian (Profeta, 2006). Siti, Norliya and Kasmarini (2012), in the context of the communication process, mention that the performance indicator to evaluate the communication elements such as the use of polite language and style, follow-up regarding users' satisfaction and questions about further information needs. They also stress that answers that being provided to the users should come with the descriptions of the information findings or from the research process. As for communication, it relates to how the librarians interact with the user.

\section{User's Satisfaction}

As mentioned earlier, user's satisfaction related to the response of the users after they use any service or product whether it meets their required needs and expectations. It is classified as dissatisfied if the users found that the services or product offered are not match with their needs and expectations. According to Okorodudu (2012), user's satisfaction of library information resources and service is a method of users gives judgment on the adequacy of the library information resources and services provided to them and if it meets with their expectations (as cited in Tiemo \& Ateboh, 2016). Library users' satisfaction shows the feel of the users after using the library services and their willingness to use the service again the other time they need information. They added that, the definition of user's satisfaction in the library context as "the satisfaction users derived from the library by using the various types of information resources and services to fulfill their information needs for their various daily activities". At the same time, measurement and evaluation activities at the academic libraries are very crucial in ensuring the library in monitoring the level of users' satisfactions towards the resources and services offered to the library users (Wan Nor Haliza et. al., 2017).

\section{Methodology}

In order to conduct this study, a survey method is adopted to answer the research questions. In this study, a set of questionnaires were distributed to random users which among the students of the academic institution in one academic library in Malaysia. 231 sets of questionnaires out of 344 sampling were returned to the researchers to be analyzed. The raw data received then being analyzed by using the appropriate software which is the most common use by many researchers which is the Statistical Package for Social Science (SPSS) version 22. 
Vol. 7, No. 3, July 2018, E-ISSN: 2226-6348 @ 2018 HRMARS

\section{Results}

\section{Profile of the Respondents}

The respondents of this study are among the students of one academic institution in Malaysia. In total, of 231 respondents, 198 or $85.7 \%$ respondents are female meanwhile 33 or 14.3\% respondents are male. The majority of the respondents are around the age of 21-25 years, which includes 220 respondents, followed by the age from 26-30 which the total of respondents of 6 . Another 4 respondents are from the age 31-35 and lastly only 1 respondent from the age 36-40. In terms of mode of the study of respondents, the majority of the respondents are the full time students with 225 respondents with $97.4 \%$ and only 6 respondents with $2.6 \%$ are part time students.

\section{Services Accessibilities}

In terms of the services accessibility it shows the easiness of using the reference service. The result shows that 126 respondents or $54.5 \%$ say that the level of difficulty is natural which means not too easy and not too difficult. Followed by 85 respondents or $36.8 \%$ mention that the use of reference service is easy to use, 12 respondents or $5.2 \%$ highlight it was very easy, 6 respondents or $2.6 \%$ found it was difficult and lastly only 2 respondents or $0.9 \%$ out of 231 respondents stress that it was very difficult to use this service.

Besides that, from the data collection, it shows the preferred services that want to be used by the respondents. Based on this result, reference desk has the lowest score, therefore it can be said that the reference desk is more preferable service, followed by "Ask a Librarian", then social media, e-mail, telephone and lastly is the fax service. Table 1 shows the preferred reference service rank by the respondents.

Table 1: Preferred reference service

\begin{tabular}{|r|r|r|r|r|c|}
\hline \multicolumn{1}{|l|}{ Median } \\
\hline Email & Ask A Librarian & Social media & Reference desk & Telephone & Fax \\
\hline 4.00 & 2.00 & 3.00 & 1.00 & 5.00 & 6.00 \\
\hline
\end{tabular}

\section{Responsiveness Of Librarian}

The result shows that the majority of the respondents received response from the librarians. The result shows that 222 respondents received response from the librarians and only 9 respondents or $3.9 \%$ mention that they do not receive any response. In terms of the time taken for the librarians to give a response to the students, the result shows 190 respondents or $82.3 \%$ say that the time taken for the librarians to give response meets with their expectation meanwhile 41 respondents or $17.7 \%$ said that the time taken was not met with their expectation.

\section{Quality Of Librarian's Answer}

In terms of the quality of librarian's answer, the result shows that 134 respondents or $58 \%$ stated that the answer is accurate and includes sources of information. Followed by 41 respondents or $17.7 \%$ agree that the answer is accurate, but lack of sources of information and next, 37 respondents or $16 \%$ said that the answer is partly accurate and includes sources of information. 11 respondents or $4.8 \%$ mention that the answer is partly accurate, but lack of sources of 
Vol. 7, No. 3, July 2018, E-ISSN: 2226-6348 @ 2018 HRMARS

information. 3 respondents or $1.3 \%$ say that the answer is inaccurate, but lacks of sources of information and 3 respondents or $1.3 \%$ also said that answer indicates don't know type of response. Lastly, 2 respondents or $0.9 \%$ reveal the answer is inaccurate and include sources of information.

\section{Librarian's Communication Approaches}

For librarian's communication approaches, it can be seen on how well the librarians communicate with the users. The result shows that 169 respondents or $73.2 \%$ agree that the librarians do the reference interview with the students in order to get more information on what the students need. Another 62 respondents or $26.8 \%$ say the librarians did not ask any further question in order to have better understanding of the students' queries. Another result shows whether the librarians give clear and understandable response or answer. 207 respondents or 89.6\% mention that librarians provide clear and understandable response and another 24 respondents or $10.4 \%$ mention librarians provide no clear and understandable response. It is important to know whether the answer provided is sufficient to the users or not. Thus, a question related to this element is embedded and the result outcome shows 179 respondents or $77.5 \%$ agree the librarians have asked whether the answer provided fulfil the users expectations. Another 52 respondents or $22.5 \%$ stress that the librarians never asked if the response fulfil the students' demands.

\section{User's Satisfaction}

The user satisfaction on the reference services from the respondents is moderate whereby the overall mean score is 3.48. The results show that respondents are satisfied with the competent and helpful (mean $=3.58)$, good communication skills (mean $=3.57)$, reference service $($ mean $=$ 3.52 ), answer given (mean $=3.50$ ), adequate training on the use of reference services and resources (mean= 3.49), flexible in providing reference services in different format (mean $=3.49$ ), response time (mean $=3.45)$, welcoming and user friendly (mean $=3.40$ ) and always get a reply later if reference question cannot be answered right away (mean $=3.30$ ). Table 2 shows the means scores of the perception on user's satisfaction.

Table 2: Means scores of perception on user satisfaction

\begin{tabular}{|c|c|c|}
\hline Statement & Mean & $\begin{array}{l}\text { Std. } \\
\text { Deviation }\end{array}$ \\
\hline Reference librarians and staff are competent and helpful. & 3.58 & .717 \\
\hline The environment of reference services is welcoming and user friendly. & 3.40 & .789 \\
\hline Reference librarians and staff demonstrate good communication skills. & 3.57 & .706 \\
\hline Library provides adequate training on the use of reference services and resources. & 3.49 & .703 \\
\hline $\begin{array}{l}\text { Reference librarians and staff are flexible with providing reference services in different } \\
\text { format (e.g, telephone, e-mail, social networking and online chat). }\end{array}$ & 3.49 & .715 \\
\hline $\begin{array}{l}\text { If my reference question cannot be answered right away, I will always get a reply later from } \\
\text { the library regarding my question. }\end{array}$ & 3.30 & .770 \\
\hline I am satisfied with the answer given. & 3.50 & .734 \\
\hline I am satisfied with the response time. & 3.45 & .749 \\
\hline I am satisfied with the reference services provided. & 3.52 & .762 \\
\hline Overall & 3.48 & .738 \\
\hline
\end{tabular}


INTERNATIONAL JOURNAL OF ACADEMIC RESEARCH IN PROGRESSIVE EDUCATION AND DEVELOPMENT

Vol. 7, No. 3, July 2018, E-ISSN: 2226-6348 @ 2018 HRMARS

\section{Relationships between Effectiveness of Reference Services and User's Satisfaction}

Table 3 shows the correlation between the four elements of effectiveness of reference services and user's satisfaction. Based on that table, it shows that all the correlations have significant relationships. Users' satisfaction is positively and weakly correlated with librarians' communication approaches $\left(r_{s}=0.388 ; p<0.01\right)$, positively and weakly correlated with the responsiveness of librarians $\left(r_{s}=0.234 ; p<0.01\right)$, the quality of librarians' answer $\left(r_{s}=0.262\right.$; $p<0.01)$. Meanwhile, users' satisfaction and services accessibilities is positive and very weak correlated with the value $r_{s}=0.132$ and $p<0.05$.

Table 3: Correlations between Effectiveness of Reference Services and User's Satisfaction

\begin{tabular}{|c|c|c|c|c|c|}
\hline & Accessibilities & Responsiveness & $\begin{array}{c}\text { Quality } \\
\text { of } \\
\text { answer }\end{array}$ & Communication & $\begin{array}{c}\text { User's } \\
\text { satisfaction }\end{array}$ \\
\hline Accessibilities & $\begin{array}{r}1.000 \\
. \\
231\end{array}$ & & & & \\
\hline Responsiveness & $\begin{array}{l}.062 \\
.345 \\
.231\end{array}$ & $\begin{array}{r}1.000 \\
. \\
.231\end{array}$ & & & \\
\hline $\begin{array}{c}\text { Quality of } \\
\text { answer }\end{array}$ & $\begin{array}{r}.157^{*} \\
.017 \\
231\end{array}$ & $\begin{array}{r}.233^{* *} \\
.000 \\
231\end{array}$ & $\begin{array}{r}1.000 \\
231\end{array}$ & & \\
\hline Communication & $\begin{array}{l}.052 \\
.429 \\
231\end{array}$ & $\begin{array}{r}.359 * * \\
.000 \\
231\end{array}$ & $\begin{array}{r}.353 * * \\
.000 \\
231\end{array}$ & $\begin{array}{r}1.000 \\
. \\
231\end{array}$ & \\
\hline $\begin{array}{c}\text { User's } \\
\text { satisfaction }\end{array}$ & $\begin{array}{r}.132 * \\
.046 \\
231\end{array}$ & $\begin{array}{r}.234 * * \\
.000 \\
231\end{array}$ & $\begin{array}{r}.262 * * \\
.000 \\
231\end{array}$ & $\begin{array}{r}.388 * * \\
.000 \\
231\end{array}$ & $\begin{array}{r}1.000 \\
231\end{array}$ \\
\hline
\end{tabular}

*. Correlation is significant at the 0.05 level (2-tailed).

**. Correlation is significant at the level (2-tailed).

\section{Discussion and Conclusion}

The study found that there is a significant relationship between service accessibility and user's satisfaction. It shows that service accessibility is positively and very weakly correlated with user's satisfaction which is $r_{s}=0.132$ and $p$ value is $p<0.05$. From the results it shows that service accessibilities not too important towards users' satisfaction. This result supports the result from Folk (2015), where the study found that accessibility of reference services in terms of service points and hours is not important as the awareness generated by the library instruction sessions. It means that even there is variety of reference service medium provided, but if there is a lack of awareness of that service, users will not use the service and it will reflect to the users' satisfaction. Another issues arose is, nowadays almost all of the questions can be answered through internet and this indirectly effect the students preference in using the library services. 
Vol. 7, No. 3, July 2018, E-ISSN: 2226-6348 @ 2018 HRMARS

Then, the analysis of this study found that there is a significant relationship between the responsiveness of librarians and users' satisfaction. It shows the responsiveness of librarians are positively and weakly correlated with users' satisfaction with value $r_{s}=0.234$ and $p$ value is $p<0.01$. Meanwhile, study by Norazah and Norbayah (2013), found that the responsiveness and users' satisfaction are positive and strongly correlated with the value $r=0.605, p<0.01$. This is because the responsiveness of librarians affects the users' satisfaction as users usually want their questions being solved and answered by the librarians. However, these two results is contrasted with the result found by Wang and Shieh (2006), where they found that responsiveness do not have any significant relationship with users' satisfaction with value $r=0.195$. Librarian need to give more attention to this element as they need to ensure all of the questions received are being answered or at least give some feedback to the users so that users will know the librarians are willing to help them.

In term of quality of answer, study found that there is a relationship between the quality of answer and users' satisfaction. It shows that there is a weak positive correlation between the quality of librarians' answers with the users' satisfaction with the value $r_{s}=0.262$ and $p$ value is $p<0.01$. Study by Norazah and Norbayah (2013), also found that there is positive and weak correlation between reliability and the users' satisfaction with value $r=0.356, p<0.01$. Meanwhile, the study by Wang and Shieh (2006) found that there is positive and strong relationship between quality of librarians' answers and users satisfaction with value $r=0.576$. In these two studies, they use term reliability instead of quality of answers. Quality of librarians' answers is one of the elements that are important to the users' satisfaction. This is because the purpose of users using the library services and resources are to get the high quality information that reliable and valid to be used in their works. Accuracy of responses and use of direct and indirect answers were different for the various types of query (Stacy-Bates, 2003). However, librarians should offer highquality reference services and resources without having bias on the type of query received. It means that the librarians should carefully provide the complete answers and ensure the answers are satisfied by the users. In order to provide the best answers, librarians should have high skills in seeking and searching for current, reliable, and valid information so that a high quality answers can be provided to the users.

Last but not least, this study found that there is a relationship between the communication and users' satisfaction. It shows the responsiveness of librarians is positive and moderately correlated with users' satisfaction which is $r_{s}=0.388$ and $p$ value is $p<0.01$. Librarians' attitudes in serving the users are also important in order to maintain the users' satisfaction. By having a friendly figure and welcoming greeting in the first meeting can make the users feel more comfortable to ask a question. A study by (Luo \& Buer, 2015) found that there are cases where users avoid using the reference services because they do not feel comfortable talking to the librarians. This situation is called as library anxiety where users feel nervous or worry to approach the librarians at the reference desks. It may result from negative experiences when approaching librarians in the past or it is from their personality. Further research should be done in order to identify the reasons of their anxiety in communicating with the librarians. This situation may affect the statistics of reference desks usage. Besides that, the librarians also need to have active two way communications which means after the librarians give the answer, they need to ask the users, whether the answer provided is really meet with their needs and expectation. This activity is to ensure the users are satisfied with the answers provided. 
Vol. 7, No. 3, July 2018, E-ISSN: 2226-6348 @ 2018 HRMARS

Reference services have been debated mostly as there are some people arguing on the function of this service. They think that they do not need help from the librarians as they can do searches by themselves. Nowadays, the majority of the students used search engines like Google and Yahoo to find materials they want. Their reasons of using those options are because they are more easy and time saving. They can get the information they want directly only by conducting a simple searching. However, there will be some issues happen like the validity and reliability of the information gained besides information overload if the person that used the internet materials do not know on how to evaluate the contents they retrieved from the internet.

Therefore, in order to compete with this technology and ensuring the users is using the reference services, librarians need to take proactive actions to promote the best library services to the users. Based on the findings of this study, it can be seen that libraries have provided satisfactory services in providing information but lacking in giving response in digital media like "Ask a Librarian". As these services have been heavily used by the library users, the librarians should give the response to all questions being asked. The librarians should demonstrate their important roles in providing information to the students by giving satisfied response time with high quality information. The librarians should also enhance their skills in many fields not only the basic skills that librarians should have. They should also have other soft skills quality like information technology and communication skills. These two skills are really crucial for librarians these days. In terms of information technology skills, they should be able to manipulate and fully utilize the current technology so that they can follow the trends of the users' needs and expectations in providing library services. For communication skills, by having this skill, the librarians will be able to communicate well with the users. As for the future study, it is recommended for another researcher to do in-depth study in the reference service aspects. They may focus on one or two of the reference services like "Ask a Librarian" and reference desk to discover the different results between these two services. Other than that, researcher also may conduct the study to the other type of libraries such as public libraries and special libraries and identify the different perceptions in different environments as their users' backgrounds are different compared to the users of the academic libraries.

\section{References}

Chowdhury, G. G. (2002). Digital libraries and reference services : Present and future. Journal of Documentation, 58(3), 258-283. doi:10.1108/00220410210425809

Das, T. K., Gurey, P. \& Saha, N. C. (2009). Evaluation of current trends in reference services in lieu of a model: A case study of central library. Retrieved from http://crl.du.ac.in/ical09/papers/index_files/ical-86_171_368_1_RV.pdf

Deng, L. (2014). The evolution of library reference services: From general to special, 1876 1920s. International Journal of Libraries and Information Studies, 64(3), 254-262. doi:10.1515/libri-2014-0019

Folk, A. L. (2015). Access or awareness? Identifying relationships between reference and other dimensions of public services. Retrieved from http://www.ala.org/acrl/sites/ala.org.acrl/files/content/conferences/confsandpreconfs/20 15/Folk_Access.pdf

Glory, A. C. (2014). Accessibility and utilization of reference resources and services by students in College of Education in Anambra and Enugu states of Nigeria. Retrieved from 
INTERNATIONAL JOURNAL OF ACADEMIC RESEARCH IN PROGRESSIVE EDUCATION AND DEVELOPMENT

Vol. 7, No. 3, July 2018, E-ISSN: 2226-6348 @ 2018 HRMARS http://repository.unn.edu.ng:8080/jspui/bitstream/123456789/1756/1/Azubuike,\%20Chio ma\%20Glory.pdf.

Luo, L. \& Buer, V. B. (2015). Reference service evaluation at African academic library: the user perspective. Library Review, 64(89). 552-566. doi: 10.1108/LR-04-2015-0046

Mcclure, C., Lankes, R. D., Gross, M., \& Choltco-devlin, B. (2002). Statistics, measures, and quality standards for assessing digital reference library services: guidelines and procedures. Retrieved from http://quartz.syr.edu/rdlankes/Publications/Books/Quality.pdf

McCrea, R. (2004). Evaluation of two library-based and one expert reference service on the web. Library Review, 53(1), 11-16. doi:10.1108/00242530410514748

Norazah Mohd Suki \& Norbayah Mohd Suki. (2013). Service quality vs. customer satisfaction: Perspectives of visitors to a public university library. International Journal of Social, Behavioral, Educational, Economic, Business and Industrial Engineering, 7(2), 338-342. Retrieved from http://waset.org/publications/3586/service-quality-vs.-customersatisfaction-perspectives-of-visitors-to-a-public-university-library

Profeta, P. C. (2006). Effectiveness of asynchronous reference services for distance learning students within florida's community college system. Retrieved from http://search.proquest.com.ezaccess.library.uitm.edu.my/docview/304909777?pqorigsite=summon

Ramos, M. S. \& Abrigo, C. M.(2012). Reference 2.0 in action: An evaluation of the digital reference services in selected Philippine academic libraries. Library Hi Tech News, 29(1), 8-20. doi:10.1108/07419051211223426

Ranasinghe, W. M. T. D. (2012). New trends of library reference services. Retrieved from http://eprints.rclis.org/28672/1/New\%20Trends\%20of\%20Library\%20Reference\%20Servic es.pdf

Siti Kahiriyah Nordin, Norliya Ahmad Kassim \& Kasmarini Baharuddin. (2012). Evaluating digital reference service in university libraries. 202-206. doi: 10.1109/ISBEIA.2012.6422870

Sriram, B. \& Rajev, M. K. G. (2014). Impact of academic library services on user satisfaction: Case study of Sur University College, Sultane of Oman. Journal of Library \& Information Technology, 34(2), 140-146. Retrieved from http://www.publications.drdo.gov.in/ojs/index.php/djlit/article/viewFile/4499/3744

Stacy-bates, K. K. (2003). E-mail reference responses from academic ARL libraries: An unobtrusive study. Retrieved from http://lib.dr.iastate.edu/cgi/viewcontent.cgi?article=1043\&context=refinst_pubs

Tiemo, P. A. \& Ateboh, B. A. (2016). Users' satisfaction with library information resources and services: A case study College of health Sciences Library Niger Delta University, Amassoma, Nigeria. Journal of Education and Practice, 7(16), 54-59. Retrieved from http://files.eric.ed.gov/fulltext/EJ1105267.pdf

Wang, I. \& Shieh, C. (2006). The relationship between service quality and customer satisfaction: The example of CJCU library. Journal of Information \& Optimization Sciences, 27(1), 193-209. Retrieved

from https://pdfs.semanticscholar.org/211d/68d93c4f4748cf0d8e50b6af13e16d0ef01d.pdf 